\title{
HISTOCHEMICAL EVALUATION OF IRON CONTENT IN THE LIVER OF WILD FEMALE OHRID TROUT (SALMO LETNICA KAR.) ALONG THE BREEDING CYCLE
}

\author{
Maja Jordanova ${ }^{* *}$, Katerina Rebok ${ }^{1}$, Maria João Rocha ${ }^{2,3}$, Eduardo Rocha $^{2,3}$ \\ ${ }^{1}$ Laboratory of Cytology, Histology and Embryology, Institute of Biology, Faculty of Natural Sciences \\ and Mathematics, Ss. Cyril and Methodius University, Republic of Macedonia \\ ${ }^{2}$ Laboratory of Histology and Embryology, Institute of Biomedical Sciences Abel Salazar - ICBAS, \\ University of Porto - U. Porto, Portugal \\ ${ }^{3}$ Histomorphology, Physiopathology and Applied Toxicology Group, Interdisciplinary Centre of Marine \\ and Environmental Research - CIIMAR, University of Porto - U. Porto, Portugal \\ *e-mail: majaj@pmf.ukim.mk
}

\begin{abstract}
Iron is an essential micronutrient for the normal metabolism of all cells. Intracellular iron varies within normality ranges, and depletion or overload of brings serious consequences. As such, iron can also be deleterious when appearing as an environmental toxicant. The aim of this study was to estimate semi-quantitatively the liver iron content in female Ohrid trout, from the Lake Ohrid, during the breeding cycle. Seasonal variations in hepatocytic iron were observed. The maximum content occurred at post-spawning, which was significantly higher than loads detected at pre- and earlyvitellogenesis. Positive correlations existed between iron amounts and stages of ovary maturation. By the contrary, there were no correlations between iron contents and plasma oestradiol levels. The new uncovered "iron-breeding association" strongly endorses that normal seasonal variations in hepatocytic iron content should be taken into consideration in field studies investigating and monitoring the metal burden and toxicological effects of metals on wild fish.
\end{abstract}

Key words: iron; liver; Ohrid trout; oestradiol; seasonal

\section{INTRODUCTION}

Taking into account that large number of toxic chemicals were present in the environment, eutrophication, and, potentially, global climate changes, wildlife population in aquatic ecosystems throughout the world is faced with a wide variety of stressors. In such ecosystems, among other species, fish do bioaccumulate multiple environmental contaminants, and their presence/overload may well be taken as an indicator of environmental contamination [1-4]. Besides, in the assessment of heavy metal pollution of lake ecosystems, fish have proved to be the appropriate indicator organism [5].

Information regarding either the natural background of heavy metals in Lake Ohrid - one of Europe's deepest and oldest - or the loading by human activity is rather limited. There is only one available report on heavy metal concentrations in organic samples (of liver and muscle) in fishes from Lake Ohrid [6]. Results of this study imply a possible metal contamination problem in the Lake, at least at the time. Metal pollution in aquatic ecosystems has deleterious effects on different organs. The liver is one of them and it may increase the concentration of metals in the tissue [5, 7-8]. However, the body, organs (muscle, gill and liver), tissue burden of metals seems to be influenced by the fish age, body size, condition and nutrition [5, 7]. In addition, certain authors exposed seasonal variations in the occurrence of metals in fish living in metalcontaminated lakes [8].

In view of the afore mentioned context, we aim here to investigate hystochemically iron content 
in the hepatocytes of Ohrid trout (Salmo letnica Kar.), and to explore if eventual correlation between, on the one hand, iron load and, on the other hand, ovary maturation stages and oestradiol levels exsist. This trout is endemic of Lake Ohrid, having an invaluable biological role as the local natural predator, besides being of considerable economic value and of potential use as a bioindicator species. As there is a need to know seasonal patterns of liver iron in bioindicator, and because of the risks associated with using "metal-loaded" fish in human consumption, our study is of substantial interest.

\section{MATERIAL AND METHODS}

Ohrid trout female $(\mathrm{n}=30$, range $420-1300$ g) were collected from the Lake Ohrid $\left(41^{\circ} 05^{\prime} \mathrm{N}\right.$, $\left.20^{\circ} 45^{\prime} \mathrm{E}\right)$ from October 2001 until September 2002. The use of archive in this $1^{\text {st }}$ study is justified because there are ongoing restrictions for trout fishing in Ohrid. After the capture, the animals were rapidly sacrificed by severing the spinal cord. Blood samples were taken from the caudal vein, for measuring plasma levels of oestradiol $\left(\mathrm{E}_{2}\right)$. The liver and gonads were dissected and weighted. The gonadosomatic index (GSI), used here in correlation analysis, was calculated as: ovary mass $\times 100 /$ body mass. The liver and gonads were sliced and systematically sampled so that at least 5 slabs of each organ per animal were fixed in Bouin's fixative for 48 hours.

The fixed fragments were routinely processed to paraffin and sectioned at $5 \mu \mathrm{m}$. Liver sections were stained with Perls' stain, for detection of iron, and ovary sections with hematoxylin and eosin. The iron content in the cytoplasm of hepatocytes was evaluated semi-quantitatively, based on the amount of histochemical staining, using the flowing scores: $0=$ absent $; 1=$ rare $; 2$ = common; and $3=$ abundant . For such analysis, one section was selected from each block. Twenty fields per section were quantified, at a final magnification of $400 \times$.

To characterize the maturation stage, sections from ovaries were qualitatively analysed. The gonadal maturation cycle was divided in six stages: Previtellogenesis, Early-vitellogenesis, Mid-vitellogenesis, Late-vitellogenesis, Spawning and Postspawning stage [9].

Plasma levels of $\mathrm{E}_{2}$ were measured with an enzyme immunoassay performed in 96-well plates, following the manufacturer's instructions (ACE ${ }^{\mathrm{TM}}$ EIA, Ref 582251, Cayman Chemical, USA). Each fish was assayed using two dilutions and running every sample in two technical replicates. Absorbance measurements (at $414 \mathrm{~nm}$ ) were made in a mi- croplate reader (Multiskan EX). The values for $\mathrm{E}_{2}$ (and GSI) were used here only for making statistical correlation analyses, as detailed data for the same set of fish were previously published $[9,11]$.

Iron content per group is presented as median, accompanied by the respective minimum and maximum values. For statistical inferential analyses, the software Statistica 7.0 for Windows was applied. Differences between groups were first evaluated by using Kruskal-Wallis ANOVA, followed by MannWhitney $U$-test (with Bonferroni correction) whenever the ANOVA was statistically significant. $\mathrm{E}_{2}$ plasma levels and GSI data were used for correlation analyses only. The Spearman correlation analysis was used to investigate the associations between the liver iron load and either the GSI or the $\mathrm{E}_{2}$ levels. Differences were considered significant when $\mathrm{p}$ $<0.05$.

\section{RESULTS}

With the Perls' staining, the iron in hepatocytes were revealed as blue granules (Figure 1). The semi-quantitative data on the iron load are presented in Figure 1, with animals grouped per gonadal maturation stage. Iron was not found in most fish in Pre vitellogenesis, Vitellogenesis and Spawning. However, its content was higher in Post spawning, particularly when compared to Pre and Early vitellogenesis (Figure 2). Both Late vitellogenesis and Spawning had "transition scores", unveiling a rising trend for the liver iron that culminates and Post spawning. Overall, the median rose from 0 at Pre/Early vitellogenesis to 3 (maximum) at Post spawning.

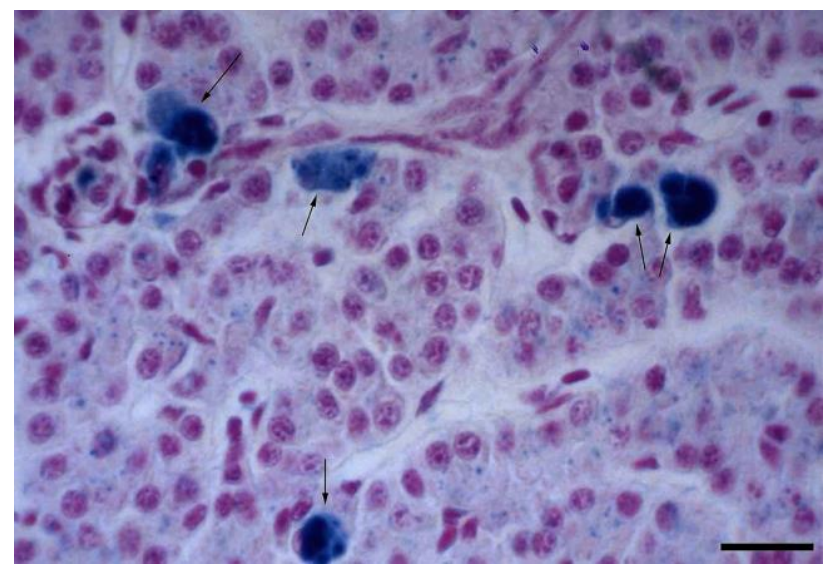

Figure 1. Micrograph of the Ohrid trout liver, displaying the iron content as blue granules within hepatocytes.

Note the aggregates of pigmented macrophages laden with hemosiderin pigment. Paraffin section. Perls' stain. Bar $=20 \mu \mathrm{m}$. 
Eventual correlations between the GSI or $\mathrm{E}_{2}$ levels and iron content was also considered. Curiously, there was a significant positive correlation between the GSI and iron load $\left(\mathrm{r}_{\mathrm{s}}=0.54 ; p<0.001\right)$, but no correlation at all between the latter content and $\mathrm{E}_{2}$ levels $\left(\mathrm{r}_{\mathrm{s}}=-0.07 ; p=0.71\right)$.

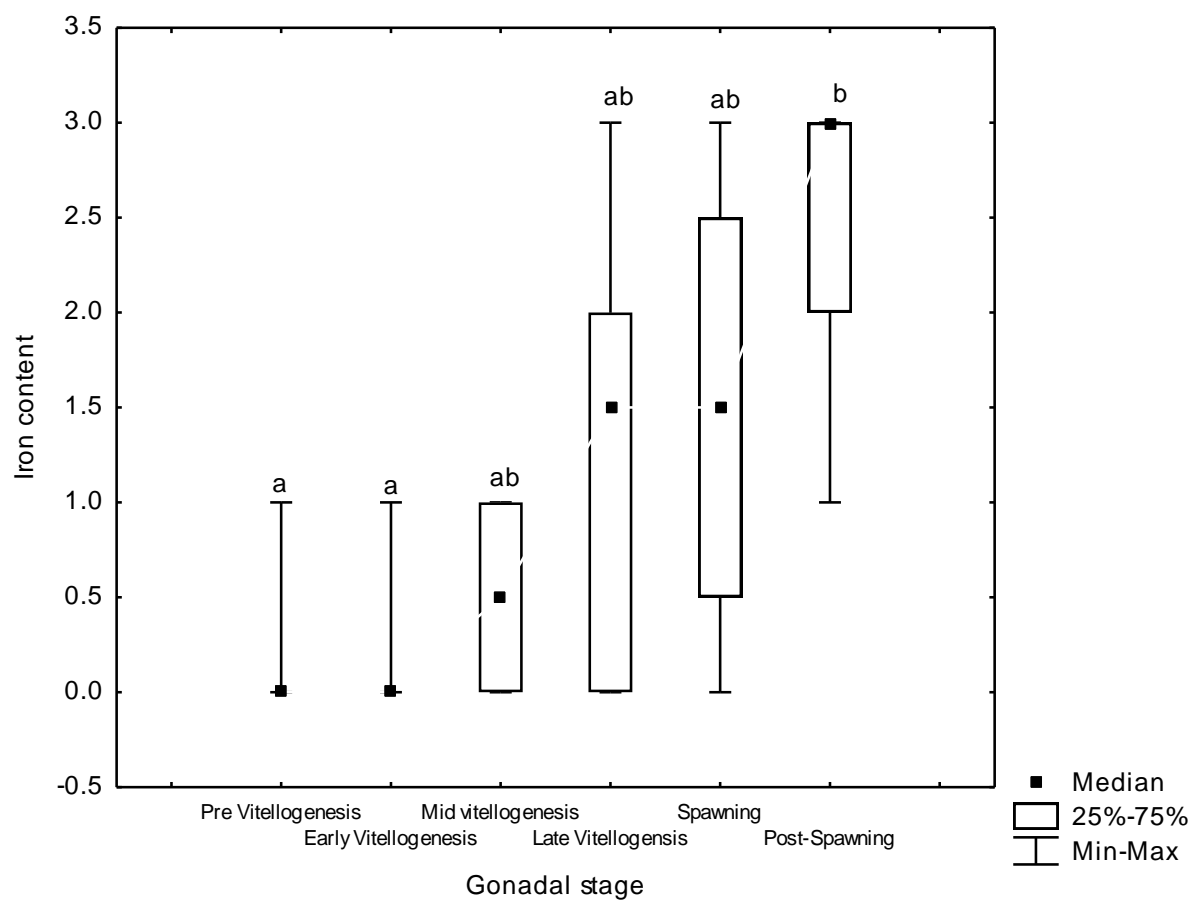

Figure 2. Iron load in the hepatocytes of Ohrid trout, during the breeding cycle, given as semi-quantitative Grades. Data sets with different superimposed letters differ significantly $(\mathrm{p}<0.05)$.

\section{DISCUSSION}

Typically, fish are top consumers in the aquatic food chain. If living under heavy metal contamination, they often bioaccumulate many metals. In this study, histochemistry and semi-quantification at light microscopy were applied to investigate the seasonality of liver iron load in Ohrid trout, possibly in connection with the stage of ovary maturation and the $\mathrm{E}_{2}$ plasma levels. The data showed almost an iron absence at Pre/Early vitellogenesis and a peak at Post spawning.

It is generally accepted that the concentration of heavy metals in the organs of fish is primarily determined by the level of pollution of water and food [5]. Thus, on a first analysis, at least the highest iron content in the Ohrid trout liver could be caused by metal overloading in the lake, therefore indicating a potential metal stress for the biota. This scenario is in line with earlier biochemical results for some fishes (including Ohrid trout) from Lake Ohrid [6].

However, the significant peak of iron during only one period of the reproductive cycle, preceded by a rising trend, along with a linear positive correla- tion with the GSI, can be related primarily to seasonal changes in physiological processes. In fact, rather than translating pollution trends only, changes in iron hepatic levels seem to be primarily governed by factors such as growth and metabolism, metal binding or changes in the feeding behaviour $[5,7]$, age structure, body size, and condition of the fish [5].

The differences within the Ohrid trout population - from near absence to high levels in Post spawning - could also be related, respectively, to a higher or to a lower lipid content during the breeding cycle. The higher tissue lipid content in fish samples was shown to cause a relative dilution of organ-accumulated micropollutants [5, 7]. In addition, in the liver of the platy fish, Xiphophorus maculatus, whose hepatocytes usually contain iron granules, those rich in lipid droplets lacked iron granules [10]. This fact perfectly agrees with our results, since Ohrid trout in the final stage of maturation in Post spawning contained a large amount of iron, but no lipid droplets in the hepatocytes [11]. Moreover, it was suggested that hepatic iron overload might be associated with hepatocytes apoptosis [12], and a cascade of death of hepatocytes by apoptosis was proposed to occur following spawning, at 
least in brown trout Salmo trutta [13]. Finally, it was proposed that the variability of iron content and distribution in the liver of female lamprey, Petromyzon marinus, might be due to changes in the rate at which iron is used in vitellogenesis [14]. Accordingly, in fish ovary, as shown in swordfish, Xiphophorus gladius, that iron (as $\mathrm{Fe}^{3+}$, detected by Perls' staining) accumulates in oocytes yolk granules and intergranular cytoplasm [15]. Here, the correlation of iron load with GSI but not with plasma $\mathrm{E}_{2}$ levels suggests that there is no direct control of the latter on hepatocytic iron storage, but it supports an $E_{2}$ independent iron uptake of hepatocytes to support increasingly iron-dependent needs with ovary maturation.

Our results indicate the importance of making a distinction between the accumulation of exogenous iron sources and the possible normal changes in tissue iron content due to endogenous factors. Therefore, in iron/metal contamination research in fish - in addition to the information about the effect of other endogenous factors, such as age, body size, condition, and nutrition on the concentrations of metals in fish organs, information regarding the natural variations that may occur during the reproduction cycle of the species must also to be considered.

Acknowledgments: Fish collections were made with the support of the Ohrid Hydrobiological Institute, Ohrid, Macedonia. Special thanks to M. Sc. Zoran Spirkovski for his great assistance in the fieldwork.

\section{REFERENCE}

[1] D. E. Hinton, R. C. Lantz, J. A. Hampton, P. R. McCuskey, R. S. McCuskey, Normal versus abnormal structure: considerations in morphologic responses of teleosts to pollutants, Environ. Health Perspect. 71 (1987), pp. 139-146.

[2] D. E. Hinton, P. C. Baumann, G. R. Gardner, W. E. Hawkins, J. D. Hendricks, R. A. Murchelano, M. S. Okihiro, Histopathologic biomarkers, in: $B i$ omarkers - Biochemical, Physiological and Histological markers of Anthropogenic Stress, R. Huggett, R. A. Kimerle, P. M. Meherle, H. L. Bergman (Eds), A special publication of SETAC Lewis Publishers Boca Raton, Ann. Arbor, London, Tokyo, 1992, pp. 155-212.

[3] D. E. Hinton, Toxicology-histopathology of fishes: a systematic approach and overview, in: Pathobiology of Marine and Estuarine organisms, J. A. Couch, J. W. Fournie (Eds), CRC Press, Boca Raton, FL, 1993, pp. 177-215.
[4] A. K. Whitfield, M. Elliott, Fishes as indicators of environmental and ecological changes within estuaries: a review of progress and some suggestions for the future, J. Fish Biol. 61:1 (2002), pp. 229-250.

[5] A. Farkas, J. Salánki, A. Specziár, I. Varanka, Metal pollution as health indicator of lake ecosystems, International J. Occupat. Medicine Environmen. Health, 14:2 (2001), pp. 163-170.

[6] Z. Spirkovski, Heavy metals and pesticides in Lake Ohrid fishes, Lake Ohrid conservation project; Lake Ohrid monitoring program; $2^{\text {nd }}$ Midterm report, Hidrobiological Inst., Ohrid (Eds), 2001.

[7] A. Farkas, J. Salánki, I. Varanka, Heavy metal concentrations in fish of Lake Balaton, Lakes Reservoirs, 5 (2000), pp. 71-279.

[8] S. Eastwood, P. Couture, Seasonal variations in condition and liver metal concentrations of yellow perch (Perca flavescens) from a metalcontaminated environment, Aquat. Toxicol. 58 (2002), pp. 43-56.

[9] M. Jordanova, M. J. Rocha, K. Rebok, E. Rocha, Changes in the amount of kidney pigmented macrophage aggregates throughout the breeding cycle of female Ohrid trout, Salmo letnica Kar. (Teleostei, Salmonidae), Microsc. Res. Tech., 75:2 (2012), pp. 176-181.

[10] I. L. Leknes, The uptake of foreign ferritin by macrophages in the spleen, trunk kidney and liver of platy, J. Fish Biol., 59 (2001), pp. 1412-1415.

[11] M. Jordanova, K. Rebok, F. Malhão, M. J. Rocha, E. Rocha, Seasonal changes in hepatocytic lipid droplets, glycogen deposits, and rough endoplasmic reticulum along the natural breeding cycle of female Ohrid trout (Salmo letnica Kar.) - A semiquantitative ultrastructural study, Micros. Res. Tech., 79:8 (2016), pp. 700-706.

[12] S. Han, Q. Tang, R. Chen, Y. Li, J. Shu, X. Zhang, Hepatic iron overload is associated with hepatocyte apoptosis during Clonorchis sinensis infection, BMC Infect. Dis., 17:531 (2017), pp. 7.

[13] E. Rocha, M. J. Rocha, M. H. Galante, M. W. Silva, R. A. F. Monteiro, The hepatocytes of the brown trout (Salmo trutta fario): A stereological study of the number and size along the breeding cycle, Ichthyol. Res., 56 (2009), pp. 43-54.

[14] J. H. Youson, P. A. Sargent, D. Ogilvie, R. R. Shivers, Morphology of the green livers in upstream migrants of Petromyzon marinus L., J. Morphol., 188 (1986), pp. 347-361.

[15] J. B. Ortiz-Delgado JB, Porcelloni S, Fossi C, Sarasquete C, Histochemical characterisation of oocytes of the swordfsh Xiphias gladius. Scien. Marina 72:3 (2008) 549-564. 


\title{
ХИСТОХЕМИСКА ПРОЦЕНКА НА СОДРЖИНАТА НА ЖЕЛЕЗО ВО ЦРНИОТ ДРОБ НА ДИВИ ЖЕНКИ ОД ОХРИДСКАТА ПАСТРМКА (SALMO LETNICA KAR.) ВО TЕКОТ НА РЕПРОДУКТИВНИОТ ЦИКЛУС
}

\author{
Маја Јорданова ${ }^{1 *}$, Катерина Ребок ${ }^{1}$, Маria João Rocha ${ }^{2,3}$, Eduardo Rocha $^{2,3}$ \\ ${ }^{1}$ Лабараторија за цитологија, хистологија и ембриологија, Институт за биологија, Природно \\ математички факултет, Универзитет Св Кирил и Методи, Република Македонија. \\ ${ }^{2}$ Laboratory of Histology and Embryology, Institute of Biomedical Sciences Abel Salazar - ICBAS, Univer- \\ sity of Porto - U. Porto, Porto, Portugal. \\ ${ }^{3}$ Histomorphology, Physiopathology and Applied Toxicology Group, Interdisciplinary Centre of Marine and \\ Environmental Research - CIIMAR, University of Porto - U. Porto, Porto, Portugal.
}

Железото е есенцијален микронутритуент потребен за нормален метаболизам на сите клетки. Интрацелуларно содржината на железо варира во рамките на нормалните граници така што деплецијата или неговото прекумерно присуство може да доведе до сериозни последици. Со оглед на ова, железото може да биде штетно и да биде токсично во животната средина. Цел на оваа студија е да се определи семиквантитативно содржината на железо во црниот дроб кај женки од охридска пастрмка од Охридското Езеро во текот на репродуктивниот циклус. Забележани се сезонски варирања во содржината на железо во хепатоцитите. Максимални вредности се евидентирани во постмрестителниот период, значително повисоки споредено со превителогенетскиот и рановителогенетскиот период. Позитивна корелација постои помеѓу количеството железо и стадиумите на созревање на овариумите. Спротивно, корелации не се евидентирани помеѓу содржината на железо и нивото на естрадиол во плазмата. Новооткриената железо репродуктивен циклус асоцијација јасно укажува дека нормалните сезонски варирања во содржината на железото во хепатоцитите треба да бидат земени предвид во студиите во кои се испитува или се прави мониторинг на заситеност со метали и токсиколошки ефект на металите врз дивите риби.

Клучни зборови: железо; црн дроб; Охридска пастрмка; естадиол; сезони 